UDC 501.1

\title{
The Use of a Genetic Algorithm in Modeling the Electrophysical Properties of a Layered Nanocomposite
}

\author{
R. P. Kim, S. P. Romanchuk, D. V. Terin, S. A. Korchagin
}

Roman P. Kim, https://orcid.org/0000-0002-7986-5810, Saratov State University, 83 Astrakhanskaya St., Saratov 410012, Russia, kimrp1988@gmail.com

Sergey P. Romanchuk, https://orcid.org/0000-0001-9828-7297, Yuri Gagarin State Technical University of Saratov, 77 Politechnicheskaya St., Saratov 410054, Russia

Denis V. Terin, https://orcid.org/0000-0003-2850-4406, Saratov State University, 83 Astrakhanskaya St., Saratov 410012, Russia, terinden@mail.ru

Sergey A. Korchagin, https://orcid.org/0000-0001-8042-4089, Engels Technological Institute of Yuri Gagarin State Technical University of Saratov, 17 Svoboda Sq., Engels 413100, Saratov Region, Russia, korchaginser@gmail.com

The research proposes an approach to solving the problem of selecting layered nanocomposite components with given electrical properties. The known methods for modeling the nanocomposites electrical characteristics are based on a preliminary analysis of such characteristics as the dielectric constant and electrical conductivity of the materials that make up a nanocomposite. The study proposes an algorithm for the selection of components of a layered nanocomposite using a genetic algorithm. Mathematical modeling of nanocomposite electrical properties is carried out using an effective medium model. We consider composite materials based on nanoporous silicon and partially oxidized porous silicon as an example. We have analyzed the frequency dependences of the dielectric constant and nanocomposite electrical conductivity when interacting with electromagnetic radiation. We have also studied efficiency of the proposed method depending on the rate of convergence and various parameters (mutation coefficient, population size, etc.). We developed a software package for modeling the electrical properties of a nanocomposite using a genetic algorithm. The results of the research can reduce the time and cost of creating new functional materials.

Keywords: genetic algorithm, mathematical modeling, layered nanocomposite, software package, effective medium model.

Received: 29.01.2019 / Accepted: 05.03.2019 / Published online: 28.05.2019

DOI: https://doi.org/10.18500/1816-9791-2019-19-2-217-225

\section{INTRODUCTION}

Layered nanocomposites are promising materials that are used in applied science (aircraft industry, astronautics, microelectronics, radar, etc.). Recent studies [1-3] show high potential for the development of design and prediction methods for nanocomposites with specified electrical properties. Works [4,5] present the problem of nanocomposite electrical properties modeling using the effective medium model (Fig. 1), the

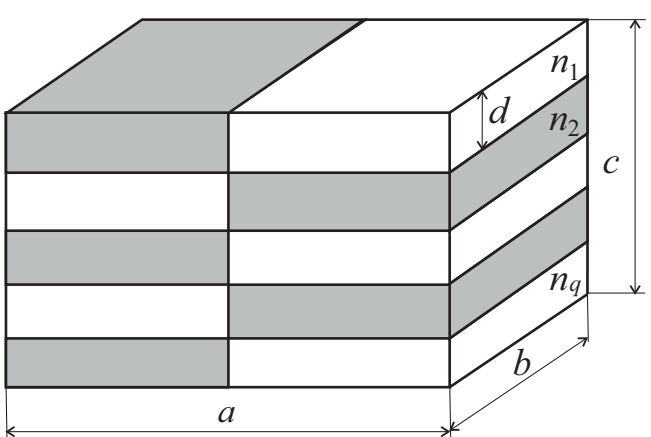

Fig. 1. Structure of layered nanocomposite 
essence of which is that a heterogeneous medium is considered as homogeneous with the same level of polarization. Such model has been proved in numerous experiments $[6,7]$, however, it has several limitations, for example, the wavelength of external radiation must be an order of magnitude larger than the dimensions of the inhomogeneities that make up the nanocomposite medium. In addition, with an increase in the number of components that make up a nanocomposite, the number of model parameters increases, which is reduced to solving polynomial equations of higher orders. When using algorithms for sequential search for roots, we can observe high computational error. Methods of simultaneous search for roots (the Abert - Erlich method [8] and the Duran - Kerner method [9]) solve this problem, however, the computation time increases, which is an important factor when conducting express analysis and observing lack of access to highperformance computing systems. In some cases, to simulate nanocomposites electrical properties we can use the method of equivalent circuits, where the nanocomposite components are represented as electrical equivalents [10]. The essence of the method lies in the possibility of using the theory of electrical circuits methods, where the task is partly solved at the stage of its formulation. In works [11,12] electrical properties were modeled using quantum mechanical methods of calculation (for example, Agranovich - Ginsburg, Kudo-Greenwood methods), which provide the most accurate results, but also require more computational power compared to other methods of modeling.

Today, researchers in the field of mathematical modeling of nanocomposites use specialized software systems, such as Gaussian, Abinit, GAMESS, SIESTA, and others. As a rule, the indicated modeling methods and their toolsets are aimed at solving the problem of direct determination of property of the resulting nanocomposite. One of the urgent tasks is the selection of nanocomposite material composition that satisfies a number of properties, for example, the dielectric constant, electrical conductivity, etc., depending on the frequency of external electromagnetic field, which is an inverse problem. Automating the process of finding the optimal composition of a nanocomposite is an important area at the crossroads of information technologies and materials science [13], which allows reducing the time and cost of designing and creating new materials with desired properties.

In the present study, the search for nanocomposite components with the required properties is implemented using a genetic algorithm [14], which is heuristic.

\section{MATHEMATICAL MODEL OF A LAYERED NANOCOMPOSITE}

A layered nanocomposite consisting of two different materials is the object of the present study (Fig. 1). The nanocomposite is described by the following parameters: $\varepsilon$ is the complex dielectric constant; $\sigma$ is electrical conductivity; $d$ is the width of the block entering into the plane-parallel layer, consisting of 2 material types (a grey block and a white block, respectively; $n$ is the layer number (the index corresponds to ordinal numbering); $a, b, c$ are the length, width and height of the nanocomposite. The values $\varepsilon$ and $\sigma$ are parameters that depend on the composition of the nanocomposite and the wavelength of the incident radiation $\lambda$. The alternation of blocks, which correspond to certain msterials and constitute the nanocomposites, occurs as the layer number grows. The values of the parameters $d, a, b, c$ can be controlled.

An effective medium model is proposed to be used as a simulation for the dielectric constant and electrical conductivity of the research object, since we consider a composite medium with parameters for which the use of this theory is permissible within 
the framework of the study. We view the layers including blocks of 5 to $40 \mathrm{~nm}$ width. The wavelength of electromagnetic radiation is an order of magnitude larger than the block sizes (from 400 to $1000 \mathrm{~nm}$ ). In this research an anisotropic medium is investigated, radiation propagates perpendicular to the layers, therefore, the corresponding pixel permittivity will appear as the tensor:

$$
\varepsilon_{e f f_{i j}}=\left(\begin{array}{ccc}
\varepsilon_{e f f_{x x}} & 0 & 0 \\
0 & \varepsilon_{e f f_{y y}} & 0 \\
0 & 0 & \varepsilon_{e f f_{z z}}
\end{array}\right)=f\left(\varepsilon_{i j_{1}}, \varepsilon_{i j_{2}}, \Delta\right),
$$

where $\varepsilon_{i j_{1}}, \varepsilon_{i j_{2}}$ is dielectric constant tensor of the blocks of 1st and 2nd material types, respectively. For the components of the tensor $\varepsilon_{e f f_{x x}}, \varepsilon_{e f f_{y y}}$ :

$$
\varepsilon_{e f f}=\frac{\sum_{k=1}^{n} \varepsilon_{i j_{k}} \Delta_{k}}{\sum_{k=1}^{n} \Delta_{k}}
$$

for $\varepsilon_{e f f_{z z}}$ :

$$
\varepsilon_{e f f}=\left(\frac{\sum_{k=1}^{n} \varepsilon_{i j_{k} \Delta_{k}}^{-1}}{\sum_{k=1}^{n} \Delta_{k}}\right)^{-1}
$$

i.e. for the investigated nanocomposite that consists of 2 materials:

$$
\varepsilon_{e f f_{x x}}=\frac{\varepsilon_{x x_{1} \Delta_{1}}+\varepsilon_{x x_{1} \Delta_{2}}}{\Delta_{1}+\Delta_{2}}, \quad \varepsilon_{e f f_{y y}}=\frac{\varepsilon_{y y_{1} \Delta_{1}}+\varepsilon_{y y_{1} \Delta_{2}}}{\Delta_{1}+\Delta_{2}}, \quad \varepsilon_{e f f_{z z}}=\left(\frac{\varepsilon_{z z_{1}}^{-1} \Delta_{1}+\varepsilon_{z z_{2}}^{-1} \Delta_{2}}{\Delta_{1}+\Delta_{2}}\right)^{-1} .
$$

The nanocomposite conductivity tensor will have the form:

$$
\sigma_{e f f_{i j}}=\left(\begin{array}{ccc}
\sigma_{e f f_{x x}} & 0 & 0 \\
0 & \sigma_{e f f_{y y}} & 0 \\
0 & 0 & \sigma_{e f f_{z z}}
\end{array}\right)=f\left(\sigma_{i j_{1}}, \sigma_{i j_{2}}, \Delta\right)
$$

where $\sigma_{i j_{1}}$ is the conductivity tensor of the blocks of the 1st and 2nd material types, respectively. The effective conductivity is found from the basic macroscopic equations $\operatorname{rot} E=0, \operatorname{div} j=0$ and Ohm's law: $j=\sigma E$. When substituting averaged magnitude $\left\langle\int_{V_{i}}^{\square} E d V\right\rangle_{i}$ with the integral of the electric field strength $E_{i}$ inside a separate block placed in a layer with conductivity tensor $\sigma_{\text {eff }}$ we obtain basic equation for the conductivity model:

$$
\sum_{i=1}^{n} v_{i}\left(\sigma_{e f f}-\sigma_{i}\right)\langle E\rangle_{i}=0,
$$

where $v_{i}$ is the dimensionless concentration of the $i$ component $\left(\sum_{i=1}^{n} v_{i}=1\right)$.

Models for a layered structure corresponding to the components $\sigma_{e f f_{x x}}, \sigma_{e f f_{y y}}$ are of the form:

$$
j=\left(\Delta_{1} \sigma_{x x_{1}}+\Delta_{2} \sigma_{x x_{2}}\right) E, \quad \sigma_{e f f_{x x u}}=\Delta_{1} \sigma_{x x 1}+\Delta_{2} \sigma_{x x 2} .
$$

For $\sigma_{e f f_{z z}}$ component:

$$
E=j\left(\frac{\Delta_{1}}{\sigma_{z z_{1}}}+\frac{\Delta_{2}}{\sigma_{z z_{2}}}\right), \quad \sigma_{e f f_{z z}}=\frac{\sigma_{z z 1} \sigma_{z z 2}}{\Delta_{1} \sigma_{z z_{1}}+\Delta_{2} \sigma_{z z_{2}}} .
$$




\section{GENETIC ALGORITHM}

The genetic algorithm is a method of optimization [15], which is based on the imitation of natural selection processes. We propose using genetic algorithm in this study. The algorithm helps to solve the problem of searching for the composition of a layered nanocomposite with specified electrical properties. The genetic algorithm works with a finite set of solutions generating new data by applying selection, mutation and crossing operators. Output, external and internal parameters are a quantitative assessment of the object properties.

The external parameters $\bar{x}=\left(x_{1}, x_{2}, \ldots, x_{n}\right)$ affect the research object (external electromagnetic radiation) and are defined as constants or functions. Internal parameters or control variables $\bar{y}=\left(y_{1}, y_{2}, \ldots, x_{m}\right)$ (composite composition, geometric parameters of blocks, etc.) describe the internal state of the object and take combination of values $\bar{y} \in Y$. Output parameters or quality parameters of the object $\bar{z}=\left(z_{1}, z_{2}, \ldots, z_{k}\right)$ (the dielectric constant or electrical conductivity of a nanocomposite) provide a numerical estimate of the nanocomposite properties and depend on the control variables $\bar{z}=\bar{z}(\bar{Y})$ To solve the problem, it is necessary to choose the most accurate solution based on quantitative index $\varphi(\varphi(\bar{Y}) \in \sigma)$. Where $\varphi$ is the output parameter scale $\gamma_{i}$. The choice of the best solution comes down to the choice of those solutions that match the lowest value of the criteria $\varphi\left(\varphi^{\prime}=\varphi\left(\bar{Y}^{\prime}\right)=\min _{\beta \in B} \varphi(\bar{Y})\right)$, where $\bar{Y}^{\prime}$ is the best solution, $\varphi^{\prime}=\varphi\left(\bar{Y}^{\prime}\right)$ is the lowest value of the criteria in the search field. As a result it is necessary to find such nanocomposite composition, where the value of the dielectric constant (conductivity) is as close as possible to the given one.

Development of the algorithm begins with the use of the smallest indivisible unit of a species subjected to evolutionary transformation. This is an individual species, which is a layered nanocomposite. It is represented by a vector of internal parameters or a
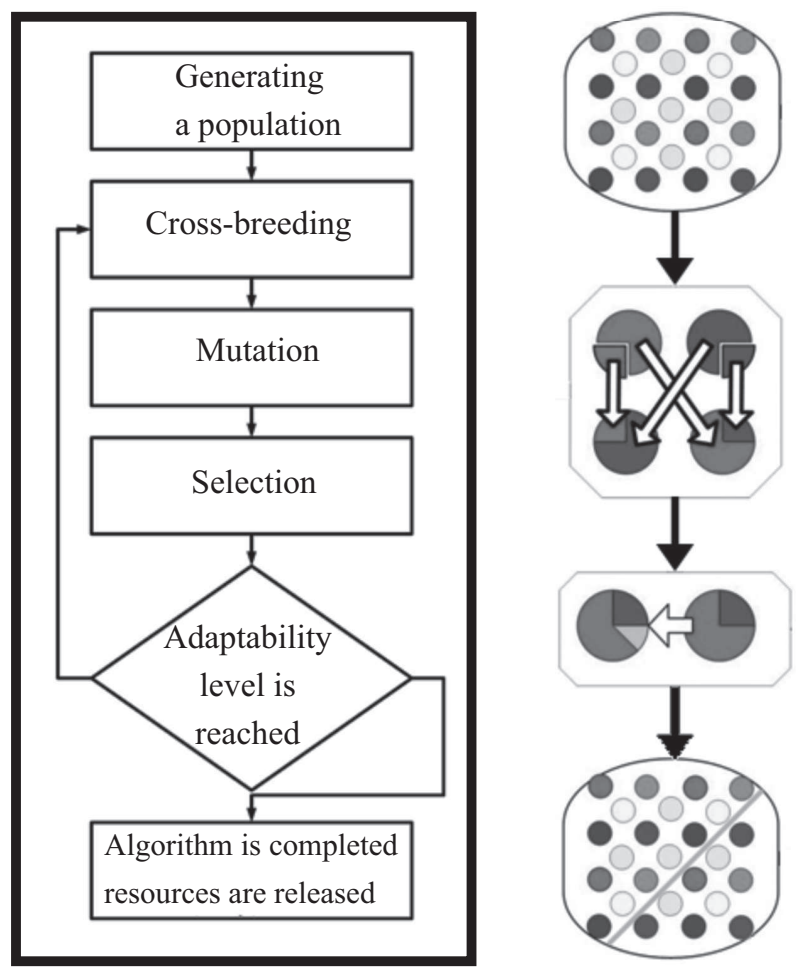

Fig. 2. General view of the genetic algorithm genotype. A phenotype (a manifestation of external features) appears in the case individual's interaction with external environment. This phenotype is characterized by individual's adaptation. Thus, there is a criterion for assessing one individual in relation to the others. The set of individuals with a similar genotype constitute a population, the area of which is the set, where individuals are located. Fig. 2 shows a general view of the genetic algorithm consisting of several main phases: generation, crossing, mutation, selection.

In the initial stage we generate the starting population and assess adaptability of an individual species. We calculate the objective function for this purpose. The next stage is cross-breeding and increasing the size. The population size depends on 
the choice of a cross-breeding mechanism, so the population can double, triple or grow in any proportion. The genotype that determines descendants of individuals varies, i.e. a new generation goes through a phase of mutation, which can take place either randomly or according to a predetermined algorithm. The next stage is the analysis of adaptability (we calculate the objective function of a nanocomposite and decide to what extent the obtained characteristics are approximate to the desired ones).

The analysis of adaptability is carried out for each individual in the next stage. Only the fittest individuals remain in the population, the rest are killed. If we find nanocomposite composition with the desired properties in this stage, the process stops, otherwise we perform transition to the cross-breeding stage.

We have implemented the genetic algorithm in the programming language $\mathrm{C}++$. Fig. 3 shows the main classes of the developed software package.

The Evolution class models evolution process (crossing, mutation, selection). We have developed the Materials class that allows us to use the properties of materials. This class allows to obtain characteristics of various materials and compounds depending on the wavelength of external

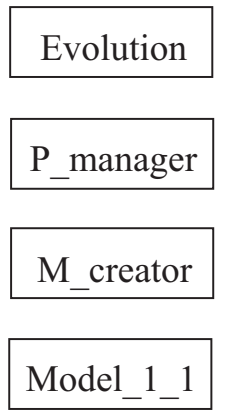

Fig. 3. Class hierarchy

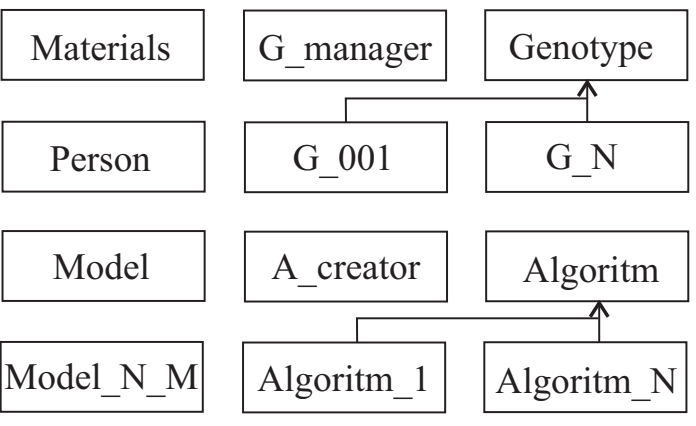
electromagnetic radiation (we have downloaded the data about the properties from the source [16]).

We have created and configured a genotype (the Genotype class) for the current task before initiation of the evolution process. Settings and management of a genotype are performed using the G-Manager class. Genotype contains a set of genotypes for various composites (structure, number of components, shape of inclusions). Then we have a generated population (the Person class) and the evolution process starts. We have developed the Model class for the objective function. This class encapsulates a method for calculating composite properties and the Algorithm class for implementing numerical methods to find the roots of polynomial equations with complex variables.

Fig. 4 shows the block diagram of the implemented genetic algorithm of the developed software package.

\section{RESULTS OF A COMPUTATIONAL EXPERIMENT}

We have considered the task of selecting layered nanocomposite components (the object of the present study) as a computational experiment. The research object should satisfy the following properties: the dielectric constant must be varied within $\varepsilon_{\text {eff }} \in[0,2 ; 0,8]$ at the wavelength of external electromagnetic radiation $\lambda \in[400 ; 1000]$. The results of the calculations have showed that the most suitable materials are $\mathrm{TiO}_{2}-\mathrm{SiO}_{2}$ components. Such materials can be used for creating a nanocomposite with the characteristics and structure considered as the research object. Fig. 5 shows graphs of the $\mathrm{TiO}_{2}-\mathrm{SiO}_{2}$ nanocomposite dependencies on the wavelength of the electromagnetic radiation. The graph shows that only a nanocomposite with parallel connection of layers corresponds to the conditions of the problem. 


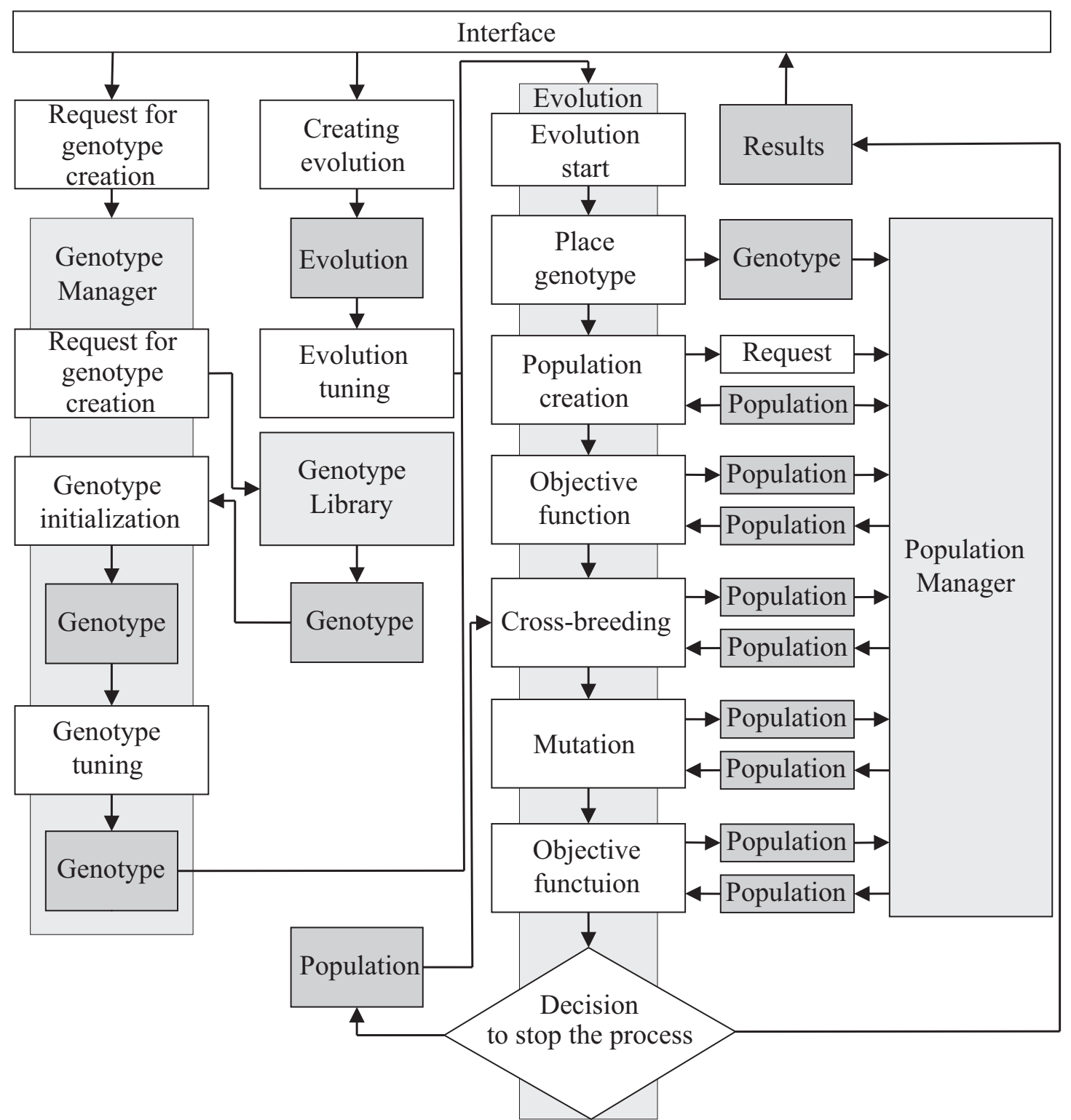

Fig. 4. Block diagram of the implemented genetic algorithm [17]

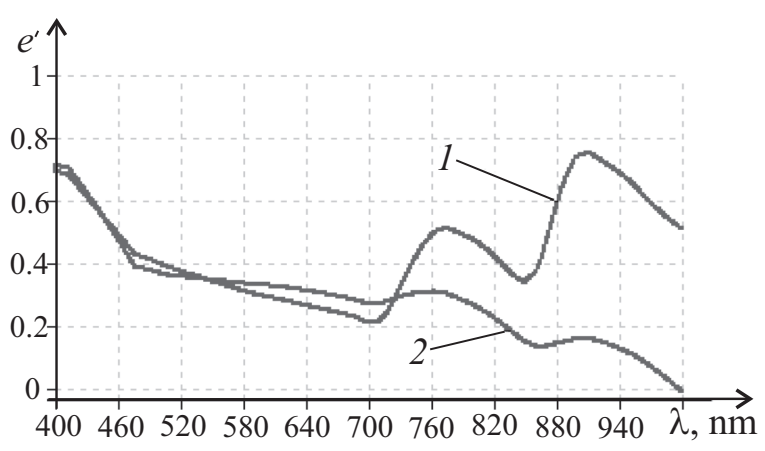

Fig. 5. The dependence of the dielectric constant on the wavelength of electromagnetic radiation: 1 - parallel connection of layers, 2 - series connection of layers
Received information about the composition of the material allows to conduct additional computational experiments which will provide additional information about the nanocomposite, for example, the dependence of the complex dielectric constant on $\mathrm{TiO}_{2}$ volume fraction entering into the nanocomposite (Fig. 6).

The results of the genetic algorithm affect such parameters as population size, mutation probability, etc. We have analyzed the effect of these parameters.

We have generated 100 experiments with random characteristics of the genotype and the same objective function for each population from 10 to 500 individuals in increments 
of 10. The number of iterations has limited evolution. Population size influences the convergence rate of the genetic algorithm. High population size allows you to describe the largest possible area for solution variants and perform more calculations per iteration.
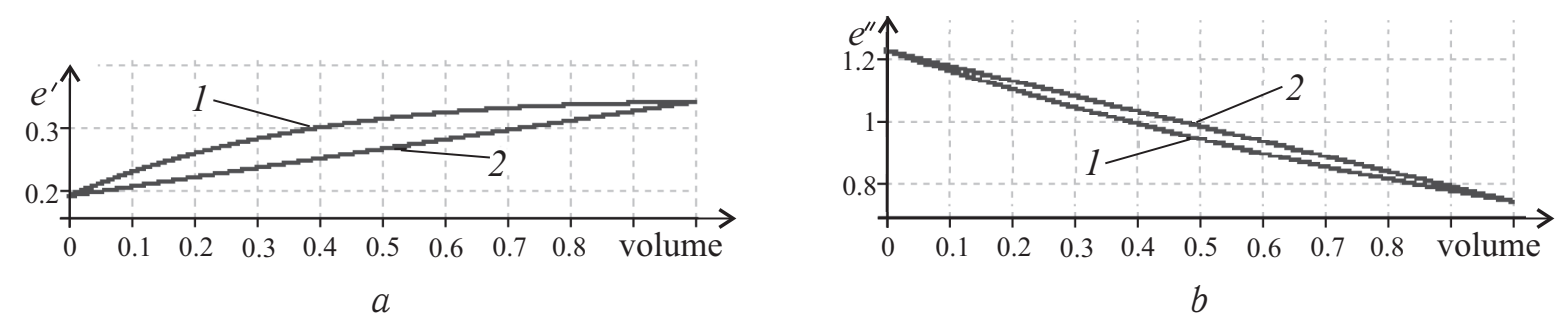

Fig. 6. The dependence of the real $(a)$ and imaginary $(b)$ parts of dielectric constant on the volume fraction: 1 - parallel connection of layers, 2 - series connection of layers

\section{CONCLUSION}

The research presents the possibility of using genetic algorithm in problems of modeling the electrical properties of a layered nanocomposite. We have developed a software package to solve the problem of predicting the electrical properties of a nanocomposite. The software package allowed us to carry out a computational selection experiment on finding optimal components for creating materials with specified characteristics. The obtained results can reduce time and cost of creating new functional materials.

Acknowledgements: This work was supported by Russian Foundation for Basic Research (project No. 18-07-00752A).

\section{References}

1. Msekh M. A., Cuong N. H., Zi G., Areias P., Zhuang X., Rabczuk T. Fracture properties prediction of clay/epoxy nanocomposites with interphase zones using a phase field model. Engineering Fracture Mechanics, 2018, vol. 188, pp. 287-299. DOI: https:doi.org/10.1016/j.engfracmech.2017.08.002

2. Vu-Bac N., Silani M., Lahmer T., Zhuang X., Rabczuk T. A unified framework for stochastic predictions of mechanical properties of polymeric nanocomposites. Computational Materials Science, 2015, vol. 96, pt. B, pp. 520-535. DOI: https://doi.org/10.1016/j.commatsci.2014.04.066

3. Zare Y., Rhee K. Y., Hui D. Influences of nanoparticles aggregation/agglomeration on the interfacial/interphase and tensile properties of nanocomposites. Composites Part B: Engineering, 2017, vol. 122, pp. 41-46. DOI: https://doi.org/10.1016/j.compositesb.2017.04.008

4. Korchagin S. A., Terin D. V., Klinaev Yu. V. Simulation of a fractal composite and study of its electrical characteristics. Mat. Mod. Chisl. Met., 2017, iss. 13, pp. 22-31 (in Russian). DOI: https://doi.org/10.18698/2309-3684-2017-1-2231

5. Balagurov B. Ya. Conduction of the three-dimensional model of a composite with structural anisotropy. Journal of Experimental and Theoretical Physics, 2016, vol. 123, iss. 2, pp. 348-356. DOI: https://doi.org/10.1134/S1063776116060017

6. Zarubin V. S., Kuvirkin G. N., Savelieva I. Yu. Evaluation of dielectric permittivity of composite with dispersed inclusions. Herald of the Bauman Moscow State Technical University. Ser. Instrument Engineering, 2015, no. 3(102). pp. 50-64 (in Russian). DOI: https://doi.org/10.18698/0236-3933-2015-3-50-64

7. Zarubin V. S., Sergeeva E. S. Application of mathematical modeling to determine the thermoelastic characteristics of nano-reinforced composites. Math. Models Comput. Simul., 2017, vol. 29, no. 10, pp. 288-298. DOI: https://doi.org/10.1134/S2070048218030134 
8. Aberth O. Iteration methods for finding all zeros of a polynomial simultaneously. Mathematics of Computation, 1973, vol. 27, no. 122, pp. 339-344.

9. Kerner I. O. Ein Gesamtschrittverfahren zur Berechnung der Nullstellen von Polynomen. Numerische Mathematik, 1966, vol. 8, pp. 290-294.

10. Korchagin S. A., Terin D. V., Romanchuk S. P. Synergetics of mathematical models for analysis of composite materials. Izvestiya VUZ. Applied nonlinear dynamics, 2015, vol. 23, no. 3, pp. 55-64 (in Russian). DOI: https://doi.org/10.18500/0869-6632-2015-23-3-55-64

11. Aleksandrov Y. M., Yatsishen V. V. Calculation of the elements of the complex dielectric tensor for anisotropic materials. Physics of Wave Processes and Radio Systems, 2015, vol. 18, no. 1, pp. 23-27 (in Russian).

12. Kasumova R. D., Amirov Sh. Sh., Shamilova Sh. A. Parametric interaction of optical waves in metamaterials under low-frequency pumping. Quantum Electronics, 2017, vol. 47, no. 7, pp. 655-660. DOI: http://dx.doi.org/10.1070/QEL16395

13. Toader G., Rusen E., Teodorescu M., Diacon A., Stanescu P. O., Damian C., Rotariu T., Rotariu A. New polyurea MWCNTs nanocomposite films with enhanced mechanical properties. J. Appl. Polym. Sci., 2017, vol. 134, iss. 28, p. 45061. DOI: https://doi.org/10.1002/app.45061

14. Kramer O. Genetic algorithm essentials. Springer, 2017. 94 p. DOI: https://doi.org/10.1007/978-3-319-52156-5

15. Huang Yu., Du L., Liu K., Yao X., Risacher Sh. L., Guo L.. Saykin A. J., Shen L. A Fast SCCA Algorithm for Big Data Analysis in Brain Imaging Genetics. Graphs in Biomedical Image Analysis, Computational Anatomy and Imaging Genetics. GRAIL 2017, MICGen 2017, MFCA 2017. Lecture Notes in Computer Science, vol. 10551. Springer, Cham, 2017. pp. 210-219. DOI: http://dx.doi.org/10.1007/978-3-319-67675-3_19

16. Handbook of optical constants of solids : in 5 vols. / ed. by E. D. Palik. San Diego, Academic Press, 1997. Vol. 3. 999 p.

17. Romanchuk S. P., Korchagin S. A., Terin D. V. Simulation of the characteristics of a nanocomposite material with spherical inclusions using the genetic algorithm. Mathematical Modeling and Computational Methods, 2018, no. 2, pp. 21-31 (in Russian). DOI: https://doi.org/10.18698/2309-3684-2018-2-2131

\title{
Cite this article as:
}

Kim R. P., Romanchuk S. P., Terin D. V., Korchagin S. A. The Use of a Genetic Algorithm in Modeling the Electrophysical Properties of a Layered Nanocomposite. Izv. Saratov Univ. (N. S.), Ser. Math. Mech. Inform., 2019, vol. 19, iss. 2, pp. 217-225. DOI: https://doi.org/10.18500/18169791-2019-19-2-217-225

\section{УДК 501.1}

\section{Использование генетического алгоритма в задачах моделирования электрофизических свойств слоистого нанокомпозита}

\author{
Р. П. Ким, С. П. Романчук, Д. В. Терин, С. А. Корчагин
}

Ким Роман Павлович, начальник отдела аппаратно-программных систем, Поволжский региональный центр новых инсрормационных технологий, Саратовский национальный исследовательский государственный университет имени Н. Г. Чернышевского, Россия, 410012, Саратов, ул. Астраханская, д. 83, kimrp1988@gmail.com

Романчук Сергей Петрович, ассистент кафедры информационной безопасности автоматизированных систем, Саратовский государственный технический университет имени Гагарина Ю. А., Россия, 410054, Саратов, ул. Политехническая, д. 77 
Терин Денис Владимирович, кандидат фризико-математических наук, доцент кафредры материаловедения, технологии и управления качеством, Саратовский национальный исследовательский государственный университет имени Н. Г. Чернышевского, Россия, 410012, Саратов, ул. Астраханская, д. 83, terinden@mail.ru

Корчагин Сергей Алексеевич, кандидат фризико-математических наук, доцент кафредры естественных и математических наук, Энгельсский технологический институт (фрилиал) Саратовского государственного технического университета имени Гагарина Ю. А., Россия, 413100, Саратовская область, Энгельс, пл. Свободы, д. 17, korchaginser@gmail.com

В статье рассматривается подход к решению задачи подбора компонент слоистого нанокомпозита с заданными электрическими свойствами. Известные методы моделирования электрических характеристик нанокомпозитов основаны на предварительном анализе таких характеристик, как диэлектрическая проницаемость и электропроводность материалов, входящих в состав нанокомпозита. В работе предлагается алгоритм подбора компонент слоистого нанокомпозита с использованием генетического алгоритма. Математическое моделирование электрических свойств нанокомпозита (в качестве примера рассмотрены композиционные материалы на основе нанопористого кремния и частично окисленного пористого кремния) осуществляется с использованием модели эсрфективной среды. Проведены анализ частотных зависимостей диэлектрической проницаемости и электропроводности нанокомпозита при взаимодействии с электромагнитным излучением, а также анализ эсрфрективности предложенного метода в зависимости от скорости схождения и различных параметров (коэсрсрициента мутации, численности популяции и проч.). Разработан программный комплекс моделирования электрических свойств нанокомпозита с использованием генетического алгоритма. Полученные результаты могут сократить сроки и издержки создания новых фрункциональных материалов.

Ключевые слова: генетический алгоритм, математическое моделирование, слоистый нанокомпозит, программный комплекс, модель эфрфективной среды.

Поступила в редакцию: 29.01.2019 / Принята: 05.03.2019 / Опубликована онлайн: 28.05.2019

Благодарности. Работа выполнена при финансовой поддержке РФФИ (проект № 18-07-00752A).

\section{Образец для цитирования:}

Kim R. P., Romanchuk S. P., Terin D. V., Korchagin S. A. The Use of a Genetic Algorithm in Modeling the Electrophysical Properties of a Layered Nanocomposite [Ким Р. П., Романчук С. П., Терин Д. В., Корчагин С. А. Использование генетического алгоритма в задачах моделирования электрофизических свойств слоистого нанокомпозита] // Изв. Сарат. ун-та. Нов. сер. Сер. Математика. Механика. Информатика. 2019. Т. 19, вып. 2. C. 217-225. DOI: https://doi.org/10.18500/1816-9791-2019-19-2-217-225 